\title{
Complex dystonias: an update on diagnosis and care
}

\author{
Rebecca Herzog $^{1}\left[\right.$ (] $\cdot$ Anne Weissbach ${ }^{1} \cdot$ Tobias Bäumer $^{1} \cdot$ Alexander Münchau $^{1}$
}

Received: 31 August 2020 / Accepted: 30 October 2020 / Published online: 13 November 2020

(c) The Author(s) 2020

\begin{abstract}
Complex dystonias are defined as dystonias that are accompanied by neurologic or systemic manifestations beyond movement disorders. Many syndromes or diseases can present with complex dystonia, either as the cardinal sign or as part of a multisystemic manifestation. Complex dystonia often gradually develops in the disease course, but can also be present from the outset. If available, the diagnostic workup, disease-specific treatment, and management of patients with complex dystonias require a multi-disciplinary approach. This article summarizes current knowledge on complex dystonias with a particular view of recent developments with respect to advances in diagnosis and management, including causative treatments.
\end{abstract}

Keywords Complex dystonia $\cdot$ NBIA $\cdot$ Infantile cerebral palsy $\cdot$ Diagnostic $\cdot$ Management $\cdot$ Red flags

$\begin{array}{ll}\text { Abbreviations } \\ \text { DBS } & \text { Deep brain stimulation } \\ \text { CP } & \text { Infantile cerebral palsy } \\ \text { CPMS } & \text { Clinical Patient Management System } \\ \text { CSF } & \text { Cerebrospinal fluid } \\ \text { ERN } & \text { European Reference Networks } \\ \text { NBIA } & \text { Neurodegeneration with brain iron accumulation } \\ \text { PED } & \text { Paroxysmal exertional dystonias } \\ \text { PKAN } & \text { Pantothenate kinase-associated } \\ & \text { neurodegeneration }\end{array}$

\section{Introduction}

Dystonia is thus currently defined as "a movement disorder characterized by sustained or intermittent muscle contractions causing abnormal, often repetitive movements or postures, or both." According to the new classification, the term "complex dystonia" is used for dystonias accompanied by neurologic or systemic manifestations beyond movement disorders. It encompasses a broad spectrum of syndromes and diseases that typically gradually evolve over time in the clinical course (Klein and Munchau 2013).

Alexander Münchau

alexander.muenchau@neuro.uni-luebeck.de

1 Institute of Systems Motor Science, University of Lübeck, Center for Brain, Behavior and Metabolism, Ratzeburger Allee 160, 23538 Lübeck, Germany
There are some characteristic dystonia features indicative of complex dystonia including sustained dystonia at rest rather than action-associated or action-specific occurrence typical for isolated or combined dystonia, and prominent tongue or perioral involvement leading to what has been labelled "risus sardonicus" (Klein et al. 1993). Typical additional signs accompanying complex dystonias are developmental delay or cognitive impairment, spasticity, ataxia, bulbar involvement including anarthria, visual impairment, oculomotor disturbances, hearing loss, or seizures (Klein and Munchau 2013).

Rational diagnostic workup and early diagnosis in complex dystonias associated with marked disability are very important for two main reasons. First, some forms of complex dystonia are treatable, so that adequate and early therapy is mandatory.

Second, as is the case also for other patients with hitherto unexplained diseases, quality of life of caregivers, particularly mothers of affected children or adolescents, significantly improves by clarifying the etiologic, usually genetic, background of a disabling disease (Lingen et al. 2016). This is probably explained by reductions of the feeling of guilt in parents, who often implicitly or explicitly fear that they are responsible for the disease of their child (Lingen et al. 2016).

With this review, we aim to highlight the important role of interdisciplinary care for patients with complex dystonias that are prototypes of rare diseases. This field advances rapidly, particularly with respect to diagnosing and treating patients, so that there is a need for a systematic summary of the current state of knowledge. 


\section{Complex dystonias in children}

After tics, dystonia is the second most common movement disorder in children (Baumer et al. 2017). In contrast to dystonia in adult patients, which is typically isolated or combined and focal or segmental, dystonia in children is complex in about $50 \%$ of cases and tends to generalize (Marsden and Harrison 1974). In fact, in $80 \%$ of patients with generalized dystonia symptoms started before the age of 15 (Marsden and Harrison 1974). The earlier symptoms begin, the higher is the probability that they worsen over time (Burke et al. 1986a). Patients with onset in the legs tend to have a more rapid spread of dystonia to other body regions than those, in whom dystonia starts in the arms (Greene et al. 1995). As regards etiology, genetically determined forms and acquired forms, including perinatal injury, are much more frequent in children than in adults, wherein the majority of cases etiology is unknown, even though a genetic cause is often suspected.

\section{Acquired forms}

\section{Infantile cerebral palsy (CP)}

Infantile cerebral palsy is the most frequent cause of acquired dystonias in children (Lin et al. 2014). The term comprises different syndromes, all resulting from brain damage for various reasons, including stroke and infection during pregnancy or perinatally. Many children also have other symptoms and signs in addition to dystonia, particularly spasticity, cognitive impairment, or epilepsy, thus qualifying to be grouped into the category of complex dystonias. In these cases, great caution is necessary not to overlook potentially treatable hereditary diseases (MacLennan et al. 2015), e.g., L-Dopa-responsive dystonia that can present as complex dystonia and be misinterpreted as CP (Giri et al. 2019; Pearson et al. 2019).

Although the classification of $\mathrm{CP}$ is a matter of ongoing debate, its core components are clear. Thus, it is a disorder of movement and posture caused by brain lesions that may be microscopic, e.g. hypoxia leading to selective necrosis of neurons often not captured by conventional brain imaging. It is acquired early in life and typically does not progress (Pakula et al. 2009). Onset though may be delayed, for instance in dyskinetic CP with symptoms becoming apparent in the first year of life, but not immediately after birth. Dystonic CP is dominated by abnormal postures that are often less dynamic and variable compared to isolated dystonias (Christine et al. 2007). In many cases, lingual, pharyngeal, and laryngeal muscles are affected leading to speech- and swallowing difficulties. MR-imaging typically shows leukoencephalopathy or lesions in globus pallidus or thalamus, but may also be unremarkable (Benini et al. 2013). Importantly, whenever there is a discrepancy between clinical phenomenology and brain imaging, e.g., a severe or complex syndrome with generalized dystonia, spasticity, and cognitive impairment associated with normal brain imaging or only subtle changes, causes other than acquired lesions have to be considered, particularly genetically determined autosomal recessive or de novo diseases (Zouvelou et al. 2019; Pearson et al. 2019).

\section{Bilirubin encephalopathy}

A special form of brain damage, that can clinically present as CP, is bilirubin encephalopathy (Rose and Vassar 2015). Particularly, the globus pallidus and nucleus subthalamicus have a predilection for being damaged by hyperbilirubinemia (Gkoltsiou et al. 2008). The etiology of hyperbilirubinemia is manifold, i.e., hemolytic disorders. Examples for specific etiologies are $\mathrm{AB} 0$-incompatibility, genetic diseases including beta-thalassemia and Glucose-6-phosphate dehydrogenase deficiency, birth asphyxia, and congenital infections, i.e., cytomegalovirus infection and syphilis (Dennery et al. 2001; Olusanya et al. 2015). The prevalence and disease burden of neonatal hyperbilirubinemia is higher in developing countries due to the lack of routine treatment, diagnostic delays, limited accessibility to medical care, and financial/ cultural constraints (Olusanya et al. 2014).

In the acute phase, newborns are hypotonic, have feeding problems, and often epileptic seizures. Additionally, they can show a characteristic high-pitched screaming. This is followed by fever, generalized hypertonia including opisthotonus, upward gaze palsy, and auditory dysfunction (Shapiro 2005). The term "Kernicterus" designates the long-term outcome of acute bilirubin encephalopathy. It is typically evident after one year of age. Clinical characteristics are hypertonia, movement disorders, auditory processing disturbance with or without hearing loss, oculomotor impairments, particularly restriction of upward vertical gaze, and dysplasia of the enamel of deciduous teeth (Shapiro 2010). First-line treatments in the acute phase are phototherapy and exchange transfusions to avoid irreversible damage (Shapiro and Riordan 2020).

\section{Basal ganglia calcification}

Asymptomatic calcifications are common in adults, especially in older people (Yamada et al. 2013). In children with complex dystonia, brain calcifications are an important clue to the underlying cause, but they are not specific (Legido et al. 1988). They can be associated with intracerebral infection (e.g., cysticercosis or toxoplasmosis), immunologic diseases (e.g., systemic lupus erythematosus), metabolic 
disorders (e.g., hypoparathyroidism), or mitochondrial diseases (Donzuso et al. 2019). There are also defined monogenic diseases causing basal ganglia calcification (see Table 1) (Tonduti et al. 2018).

\section{Monogenic diseases}

Many genetically determined diseases presenting with complex dystonias commence in childhood or adolescence. An overview is given in Table 1. Diseases that are clinically particularly relevant are described in the following section.

\section{Disorders of monoamine neurotransmitter metabolism}

Pathogenic variants in the sepiapterin reductase $(S P R)$, tyrosine hydroxylase (TH), and 6-pyruvoyl tetrahydrobiopterin synthase (PTPS) gene cause deficient synthesis of dopamine (and other monoamine acids), resulting in complex dystonia (Table 1). In contrast to heterozygous pathogenic variants in the guanosine triphosphate cyclohydrolase 1 (GCHI) gene, which cause DYT/PARK-GCH1 (Segawa syndrome), the prototype disorder of Dopa-responsive dystonia, typically presenting as combined dystonia, homozygous variants result in complex dystonia syndromes. Different from autosomal-dominant DYT/PARK- $G C H I$ dystonia, the other forms are only partially responsive to L-Dopa and require additional treatment such as tetrahydrobiopterin, 5-hydroxytryptophan, or other dopaminergic medication (Opladen et al. 2020). Patients often have oculogyric crises, hypotonia, global developmental delay, and sometimes epilepsy in addition to dystonia. These diseases usually start between birth and 6 years, i.e., earlier than DYT/PARK$\mathrm{GCH} 1$. Some are associated with hyperphenylalaninemia, which is detected in newborn screening in many countries. Many forms show distinct patterns of abnormalities of pterins and other neurotransmitters in blood, cerebrospinal fluid (CSF), and/or urine.

\section{Paroxysmal dyskinesias}

Whereas patients with paroxysmal kinesigenic or non-kinesigenic dyskinesia usually present with combined dystonia, paroxysmal exertional dystonias (PED) can occur as complex dystonia. PED is characterized by attacks of dystonia triggered by prolonged physical activities. The most recognized monogenic form of PED is the Glut1-deficiency syndrome, caused by mutations in the SLC1A2 gene, which may present with variable combinations of spasticity, ataxia, seizures, and intellectual disability in addition to paroxysmal dystonia (Pons et al. 2010). A timely start with a ketogenic diet or modified Atkin's diet can lead to dramatic improvement and is associated with an improved long-term clinical outcome (Alter et al. 2015; Amalou et al. 2016; Sandu et al. 2019).

Another recently described paroxysmal movement disorder, sometimes manifesting with dystonia, is CHOR/DYTADCY5 (Chen et al. 2012). Severe phenotypes are clinically complex and can present with developmental delay, hypotonia, chorea, and myoclonus (not myokymia) (Tunc et al. 2017). A characteristic feature is exacerbation or attacks of dyskinesia during drowsiness or during sleep without abnormalities in the electroencephalography (Chang et al. 2016).

\section{Neurodegenerative diseases}

Complex dystonias that after a period of normal development evolve gradually with progressive symptoms suggest an underlying disease leading to neurodegeneration. Clinical red flags pointing in this direction are prominent bulbar involvement, rapid progression of dystonia, oculomotor signs, associated hearing problems or vision loss, or cognitive decline and behavioral abnormalities (Schneider and Bhatia 2010). The list of possible causes is very long. Children presenting with complex dystonia often need comprehensive diagnostic workup including brain imaging, CSF examination, ophthalmological assessment, and investigation of organic acids.

Typical examples are diseases belonging to the group of neurodegeneration with brain iron accumulation (NBIAs, see below) and Westphal's variant of Huntington's disease. The latter is particularly relevant, because, in contrast to adult patients, it typically presents with a combination of dystonia, parkinsonism, cognitive dysfunction but not necessarily chorea (Letort and Gonzalez-Alegre 2013) and is therefore often overlooked or diagnosed late. Of note, even if there is no strict correlation (Quarrell et al. 2013), Huntington's disease manifests in childhood or adolescence when CAG-repeat numbers are high, which is typically the case when the disease is inherited paternally (Went et al. 1984). Potentially treatable diseases such as Niemann-Pick type C (see below) and ataxia with vitamin E deficiency should be considered, because early diagnosis and treatment are associated with better long-term outcomes.

\section{Biotin- and thiamine-responsive basal ganglia disease}

Biotin- and thiamine-responsive basal ganglia disease is an autosomal recessive inherited disease caused by biallelic mutations in the $S L C 19 A 3$ gene, which encodes for the thiamine transporter-2. The disease manifests with acute or subacute encephalopathy. It is characterized by dystonia, confusion, dysarthria, external ophthalmoplegia, ataxia, and seizures. Typical triggers are febrile illnesses (Alfadhel et al. 2013). Brain imaging frequently is a key to diagnosis, showing central bilateral necrosis in the head of the 


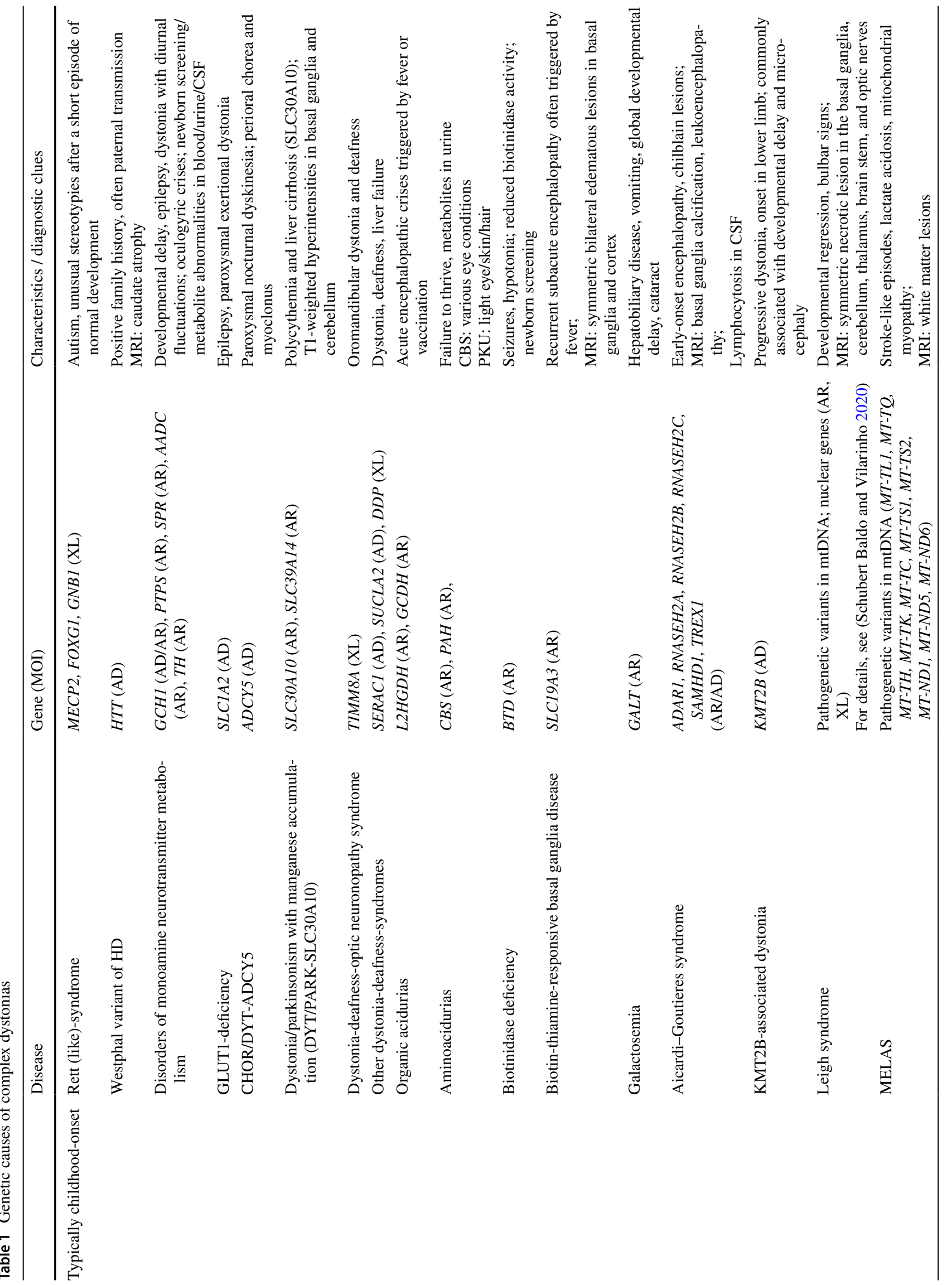




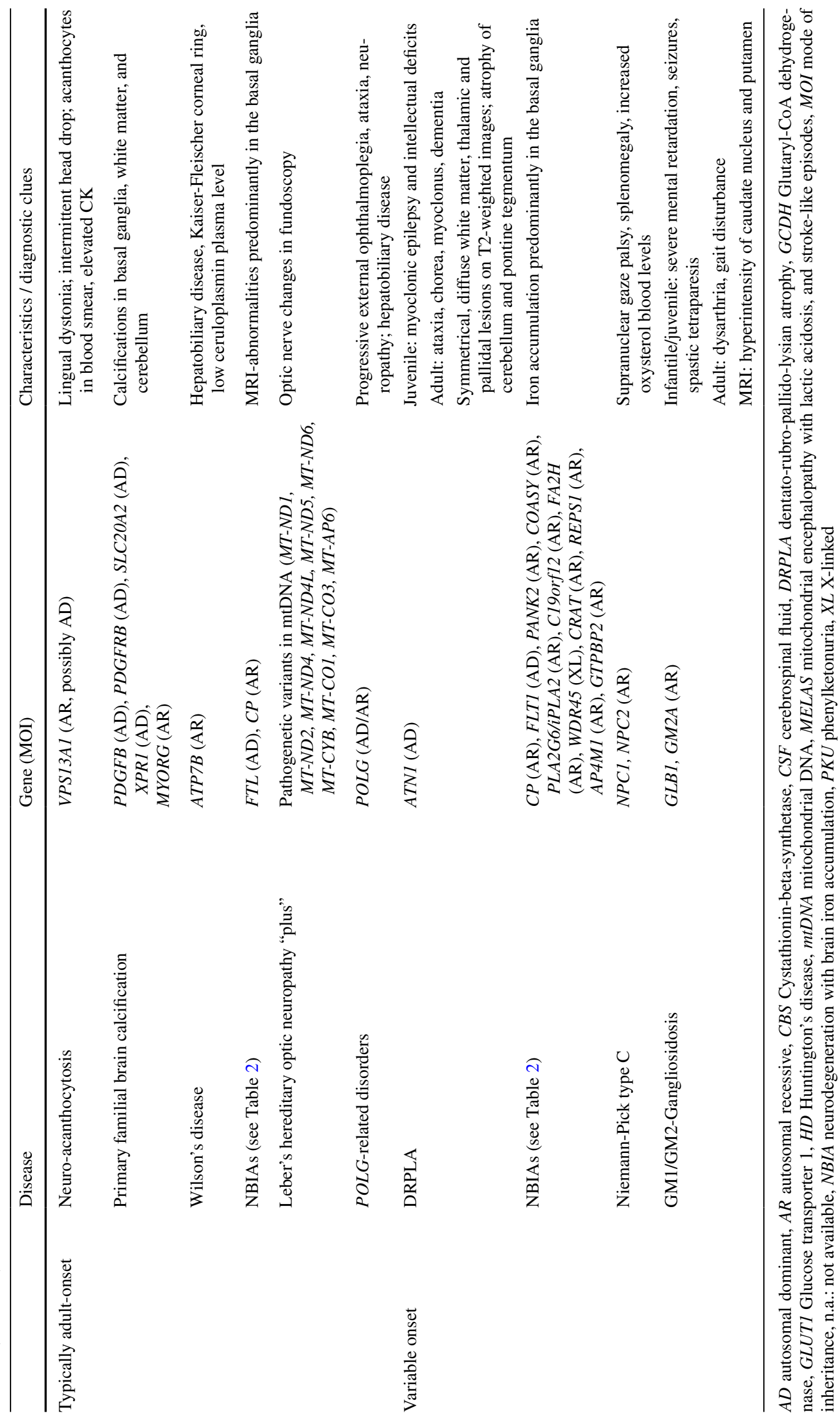


caudate nucleus and the putamen (Tabarki et al. 2013). If untreated, the prognosis is grave with the development of severe generalized dystonia and parkinsonism, quadriplegia, and epilepsy. The mortality is high (Tabarki et al. 2013). An early diagnose is very important, as sufficient treatment with thiamine and biotin can lead to significant clinical improvement (Tabarki et al. 2015).

\section{Complex dystonias in adults}

\section{Acquired forms}

There are three main scenarios of acquired dystonia in adults.

First, focal brain lesions, predominantly affecting the putamen, the thalamus, or globus pallidus, e.g. following stroke, inflammation, or surgical interventions. They can lead to contralateral hemidystonia (Munchau et al. 2000) and typically develop month or even years after the brain damage has occurred. The reason for this delay in onset is unclear, although aberrant reorganization has been hypothesized (Hinkley et al. 2009). Whereas hemidystonia can dominate the clinical picture, it is rarely the only sign. Still, it is in fact often accompanied by spasticity, sensory disturbances, particularly diminished joint position sense, or cognitive impairment, and can, therefore, be classified as complex dystonia in most cases.

Second, drugs, particularly antipsychotic medication, can cause tardive dystonia. It mostly manifests as craniocervical or oromandibular dystonia that is typically isolated or combined, but can also be complex considering that many afflicted patients also have cognitive impairment (Pourcher et al. 1993).

Third, functional movement disorders often present as dystonia and are typically accompanied by other symptoms and clinical signs (Thenganatt and Jankovic 2015), thus also qualifying to be categorized as complex dystonia.

\section{Dystonia in Parkinson and atypical Parkinson's disease}

Parkinson syndromes can present with dystonia. Patients with classical Parkinson's disease can manifest with dystonia, typically affecting the feet or legs (Shetty et al. 2019), and may also develop sometimes painful dystonia in the extremities. Obviously, dystonia in patients with parkinsonism is usually not the leading sign, but can give diagnostic clues and can be troublesome. Apart from its occurrence in classical Parkinson's disease, where it would most appropriately be categorized as combined, dystonia in other, i.e., atypical Parkinson syndromes, can be classified as complex. Thus, in patients with multiple system atrophy, facial or cervical dystonia is quite common (Thongchuam et al. 2020). Patients with progressive supranuclear palsy can have brachial dystonia or apraxia of eyelid opening (Armstrong 2011; Barclay and Lang 1997), which is considered a form of dystonia by some researchers (Krack and Marion 1994). Dystonic posturing along with rigidity and cortical sensory deficits are cardinal features of cortico-basal syndromes (Armstrong et al. 2013).

\section{Monogenic diseases}

Most monogenic complex dystonias occurring in adulthood are neurodegenerative diseases. They typically involve the basal ganglia and are sometimes associated with brain calcification or accumulation of metals, particularly copper, iron, and manganese. Brain imaging is often very helpful to identify a disease or disease-group. An overview is given in Table 1.

\section{Wilson's disease}

Wilson's disease is a representative example of a treatable genetically determined disease where metal deposition plays a crucial role. In Wilson's disease, copper accumulates in the liver and central nervous tissue due to a biallelic mutation in the $A T P 7 B$ gene. Clinical features are variable. Typically, the disease starts in adolescence or early adulthood as a hepatopathy, followed by neurological complications (Mulligan and Bronstein 2020). Diagnostic delay is longer in patients presenting with neuropsychiatric symptoms (Merle et al. 2007). Rarely, the disease commences later in life. Cases with onset in the 7th and 8th decades have been described (Ala et al. 2005). The most common neurologic features are bulbar signs, including dysarthria and dysphagia, gait abnormalities, parkinsonism, tremor, and dystonia, typically prominently involving the face leading to risus sardonicus (Machado et al. 2006; Burke et al. 2011). 30-40\% of patients have neuropsychiatric abnormalities, including apathy, indifference, and sometimes psychosis (Zimbrean and Schilsky 2014). Patients with neurological or neuropsychiatric signs have a pathognomonic Kayser-Fleischer corneal rings, i.e., copper deposits in the corneal membrane. In most patients, structural abnormalities can be identified on MRI, predominantly T2-hyperintensities involving the striatum and globus pallidus (Hermann 2014). The diagnosis can be confirmed by laboratory testing of $24 \mathrm{~h}$ urine copper assay. Investigations of free serum copper and serum coeruloplasmin can be used as screening tests. In predominantly hepatic forms, liver biopsy is the gold standard. Genetic confirmation is recommended and early treatment is essential. The mainstay of treatment is the chelation of copper, which should be started gradually given the risk of worsening symptoms initially presumably due to copper mobilization, 
particularly in patients with neurologic symptoms (Weiss et al. 2013). A novel oral copper-protein-binding agent, bischoline tetrathiomolybdate is currently under investigation (Weiss et al. 2018).

\section{Complex dystonias with variable onset}

\section{Genetically determined diseases}

\section{Niemann-Pick type C}

Niemann-Pick type $\mathrm{C}$ is caused by an autosomal recessive inherited mutation in the $N P C 1$ or $N P C 2$ gene, leading to impaired function of proteins involved in the lipid transport from cells to the extracellular matrix. Thus, toxic cholesterol accumulation causes cellular damage (Xu et al. 2019). Onset age varies significantly from the newborn period up to late adulthood (Bajwa and Azhar 2020). Typically, the disease begins in middle or late childhood. The classic phenotype is a gradually developing neuropsychiatric syndrome. It consists of frontal signs, in combination with predominantly upper body, generalized dystonia, a pan-cerebellar syndrome, and supranuclear vertical gaze palsy. These symptoms are often accompanied by an asymptomatic hepatosplenomegaly (Wijburg et al. 2012; Sedel 2010). Early diagnosis is important, because therapy with Miglustat can halt progression (Patterson et al. 2020).

\section{Neurodegeneration with brain iron accumulation (NBIA)}

NBIAs are an expanding group of progressive diseases characterized by abnormal accumulation of iron in the brain, particularly the basal ganglia, caused by different mutations with different modes of inheritance (see Table 2; Akcakaya et al. 2019; Mari et al. 2018; Rattay et al. 2019; Haack et al. 2012; Marchi et al. 2019) leading to neurodegeneration. Most patients present with movement disorders, particularly dystonia and parkinsonism. Dysarthria, spasticity, neuropsychiatric abnormalities, polyneuropathy, or visual loss are common in some forms. Onset age and progression are very variable (Gregory and Hayflick 1993). Although causative genes are involved in different biochemical pathways, brain iron accumulation is a defining hallmark. Relevant pathophysiologic mechanisms include iron oxidation deficit, free, i.e., non-transferrin bound, toxic iron, oxidative stress, lysosomal or mitochondrial dysfunction, irregular calcium homeostasis, membrane remodeling, and autophagy (Levi et al. 2019; Santambrogio et al. 2015,2020; Brissot et al. 2012; Maccarinelli et al. 2015; Seibler et al. 2018; Stelten et al. 2019). Magnetic resonance imaging, particularly iron sensitive sequences, is very helpful, because most NBIAs have characteristic patterns of abnormalities (Lehericy et al. 2020).

Pantothenate kinase-associated neurodegeneration (PKAN; NBIA/DYT-PKAN2) is the prototype and most frequent NBIA. 35-50\% of NBIAs are caused by mutations in the PANK2 gene (Hayflick et al. 2003). Typically, onset is in early childhood. Symptoms gradually progress and contain spastic-dystonic paraparesis with a tendency for dystonia to generalize, followed by dysarthria, dysphagia, and sometimes parkinsonism and behavioral problems (Kurian and Hayflick 2013). Cognition though is often intact. There is a pathognomonic "eye-of-the-tiger-sign" on $\mathrm{T} 2$-weighted images caused by focal iron accumulation in the globus pallidus, which occasionally disappears in the course of the disease (Baumeister et al. 2005). The pathophysiology remains unclear, but mitochondrial dysfunction and impaired calcium homeostasis are discussed to play a pivotal role (Santambrogio et al. 2015, 2020). Treatment with deferiprone is still under investigation, but appears to slow disease progression with a good safety profile (Klopstock et al. 2019; Rohani et al. 2017; Zorzi et al. 2011). Deep brain stimulation (DBS) of the globus pallidus internus can significantly improve dystonia (Svetel et al. 2019; Timmermann et al. 2010).

\section{Diagnostic approach to complex dystonias}

The way to a specific diagnosis for patients with complex dystonias is often long. A clear diagnostic pathway can help to prevent diagnostic delays and thus reduce disease burden for affected patients. Given that complex dystonias can occur in diseases affecting different organs in addition to the nervous system, for instance, spleen and liver in NiemannPick type C, can manifest in childhood, adolescence and adulthood and are often genetically determined, expertise from different specialties may be required. This calls for specialized centers bringing together different disciplines, which is realized, for instance, in centers for rare diseases in the context of European Reference Networks (ERNs) for rare diseases and is also facilitated by the German Academy for Rare Neurological diseases (Munchau et al. 2019). Core facilities should comprise regular multi-disciplinary case conferences according to standardized protocols. Ideally, web-based case conferences fulfilling data protection rules should also be offered. One example is the European Clinical Patient Management System (CPMS) allowing to include experts from national or international partner centers to augment diagnostic and management expertise (Smith et al. 2020). It also offers the opportunity to use virtual communication tools and DICOM viewers. The system is not only used for neurological purposes, but also in many other disciplines. If patients are sent to centers with an experienced 
Table 2 Overview of Neurodegenerations with Brain Iron Accumulation (NBIA)

\begin{tabular}{|c|c|c|c|c|c|c|}
\hline Disease & Gene (Inheritance) & Function & Onset & MRI-findings & Diagnostic clues & Causal treatment \\
\hline $\begin{array}{l}\text { Aceruloplasmine- } \\
\text { mia } \\
\text { NBIA/DYT/ } \\
\text { PARK-CP } \\
\text { (Marchi et al. } \\
\text { 2019) }\end{array}$ & $C P(\mathrm{AR})$ & $\begin{array}{l}\mathrm{Cu} \text {-dependent fer- } \\
\text { roxidase }\end{array}$ & Adulthood & $\begin{array}{l}\text { Iron accumula- } \\
\text { tion in striatum, } \\
\text { dentate nucleus, } \\
\text { and thalamus }\end{array}$ & $\begin{array}{l}\text { DM, microcytic } \\
\text { anemia, unde- } \\
\text { tectable serum } \\
\text { ceruloplasmin } \\
\text { levels }\end{array}$ & $\begin{array}{l}\text { Iron-chelating } \\
\text { therapy }\end{array}$ \\
\hline $\begin{array}{l}\text { Neuroferritinopa- } \\
\text { thy } \\
\text { NBIA/CHOREA- } \\
\text { FTL } \\
\text { (Kubota et al. } \\
\text { 2009) }\end{array}$ & FTL1 (AD) & Iron storage & Adulthood & $\begin{array}{l}\text { Lesions in globus } \\
\text { pallidus, puta- } \\
\text { men, and dentate } \\
\text { nucleus }\end{array}$ & $\begin{array}{l}\text { Decreased level of } \\
\text { serum ferritin }\end{array}$ & n.a \\
\hline $\begin{array}{l}\text { PKAN } \\
\text { NBIA/DYT- } \\
\text { PKAN2 } \\
\text { (Kurian and Hay- } \\
\text { flick 2013) }\end{array}$ & $P A N K 2$ (AR) & $\begin{array}{l}\text { Coenzyme A syn- } \\
\text { thesis; fatty acid } \\
\text { metabolism }\end{array}$ & Infancy & $\begin{array}{l}\text { "Eye-of-the tiger"- } \\
\text { sign }\end{array}$ & MRI sign & n.a \\
\hline $\begin{array}{l}\text { CoPAN } \\
\text { (Evers et al. 2017) }\end{array}$ & $C O A S Y$ (AR) & $\begin{array}{c}\text { Coenzyme A } \\
\text { synthase }\end{array}$ & Infancy & $\begin{array}{l}\text { Iron deposit in glo- } \\
\text { bus pallidus and } \\
\text { substantia nigra }\end{array}$ & Similar to PKAN & n.a \\
\hline $\begin{array}{l}\text { INAD } \\
\text { NBIA/DYT/ } \\
\text { PARK-PLA2G6 }\end{array}$ & $\begin{array}{l}\text { PLA2G6, iPLA2 } \\
\text { (AR) }\end{array}$ & $\begin{array}{l}\text { Arachidonic acid } \\
\text { release }\end{array}$ & Typical: infancy & $\begin{array}{l}\text { Iron deposit in } \\
\text { globus pallidus, } \\
\text { cerebellar atrophy }\end{array}$ & $\begin{array}{l}\text { Typical: neuropa- } \\
\text { thy with spheroi- } \\
\text { dal bodies }\end{array}$ & n.a \\
\hline $\begin{array}{l}\text { (Gregory et al. } \\
1993 \text { ) }\end{array}$ & & & $\begin{array}{l}\text { Atypical: adult- } \\
\text { hood }\end{array}$ & & $\begin{array}{l}\text { Atypical: dystonia- } \\
\text { parkinsonism } \\
\text { with psychosis } \\
\text { and dementia }\end{array}$ & \\
\hline $\begin{array}{l}\text { MPAN } \\
\text { HSP/NBIA- } \\
\text { C19orf12 } \\
\text { (Akcakaya et al. } \\
\text { 2019) }\end{array}$ & C19orf12 (AR) & Unknown & Childhood & $\begin{array}{l}\text { Iron deposit in glo- } \\
\text { bus pallidus and } \\
\text { substantia nigra }\end{array}$ & $\begin{array}{l}\text { Dystonia, neuropa- } \\
\text { thy, optic atrophy }\end{array}$ & n.a \\
\hline $\begin{array}{l}\text { FAHN } \\
\text { HSP/NBIA-FA2H } \\
\text { (Mari et al. 2018; } \\
\text { Rattay et al. } \\
\text { 2019) }\end{array}$ & $F A 2 H(\mathrm{AR})$ & $\begin{array}{l}\text { Fatty acid } \\
\text { hydroxylase }\end{array}$ & Childhood & $\begin{array}{l}\text { Iron deposit in } \\
\text { globus pallidus, } \\
\text { white matter } \\
\text { changes, cerebel- } \\
\text { lar atrophy, thin- } \\
\text { ning of corpus } \\
\text { callosum }\end{array}$ & $\begin{array}{l}\text { Spasticity, ataxia, } \\
\text { dystonia, optic } \\
\text { atrophy, bristle- } \\
\text { like hair }\end{array}$ & n.a \\
\hline $\begin{array}{l}\text { BPAN } \\
\text { NBIA/PARK- } \\
\text { WDR45(Haack } \\
\text { et al. 2012) }\end{array}$ & WDR45 (XL) & Autophagy & Childhood & $\begin{array}{l}\text { Iron deposition } \\
\text { in the globus } \\
\text { pallidus and sub- } \\
\text { stantia nigra }\end{array}$ & $\begin{array}{l}\text { Rett-like syn- } \\
\text { drome, stereo- } \\
\text { typies }\end{array}$ & n.a \\
\hline Rare forms & $\begin{array}{l}\text { CRAT, REPS1, } \\
\text { AP4M1, } \\
\text { GTPBP2 (all } \\
\text { AR) }\end{array}$ & & & & & \\
\hline
\end{tabular}

$A D$ Autosomal dominant, $A R$ Autosomal recessive, BPAN Beta-propeller-protein-associated neurodegeneration, CoPAN COASY protein-associated neurodegeneration, $D M$ Diabetes mellitus, FAHN Fatty Acid Hydroxylase-Associated Neurodegeneration, INAD Infantile Neuroaxonal Dystrophy, MPAN Mitochondrial Membrane Protein-Associated Neurodegeneration, n.a. Not available, PKAN Pantothenate kinase-associated neurodegeneration, $X L \mathrm{X}$-linked

multi-disciplinary team, this conveys benefits regarding classification, diagnostic yield, and targeted treatment strategies (van Egmond et al. 2018).

The crucial starting point of any diagnostic route is thorough clinical assessment, including family history, concomitant diseases, and organ involvement. Based on clinical acumen, further diagnostic workup is tailored. A diagnostic workup is proposed in Fig. 1.

"Red flags" for treatable diseases should always be kept in mind (see Fig. 2). In children, metabolic testing should 
be initiated parallel to neuroimaging. If a monogenic cause is suspected, diagnostic gene panels are usually preferred over single gene sequencing unless there is a high degree of suspicion for a certain disease (van Egmond et al. 2017). Whole-exome and whole-genome sequencing should be considered, particularly in cases with unusual phenotypes or suspected de novo mutations. A pre-requisite for these investigations is close cooperation between treating physicians and (neuro-)geneticists, including regular case conferences.

\begin{tabular}{|l|l|}
\hline \multicolumn{1}{c|}{ Clinical workup } \\
\hline & Medical history \\
- & Family history \\
- & Examination of other organs \\
\hline
\end{tabular}

\section{Therapeutic and long-term management}

If causative treatment is available, it should be initiated as soon as possible to improve long-term outcome and prevent unnecessary complications. Especially in inborn errors of metabolism, an early diagnosis and treatment is highly important for a good outcome (Ebrahimi-Fakhari et al. 2019). Disease-specific treatments are outlined in Table 3. In some diseases, treatments have become standard even in the absence of randomized clinical trials, as is the case, for example, for L-Dopa therapy in Dopa-responsive dystonia.

\begin{tabular}{|c|}
\hline \begin{tabular}{ll} 
& \multicolumn{1}{c}{ Further diagnostic workup } \\
- & blood/urine/CSF metabolites \\
- & MRI imaging \\
- & Blood analysis/liver ultrasound \\
- & Genetic testing (exome or panel)
\end{tabular} \\
\hline
\end{tabular}

Fig. 1 Proposal for diagnostic workup in suspected complex dystonias

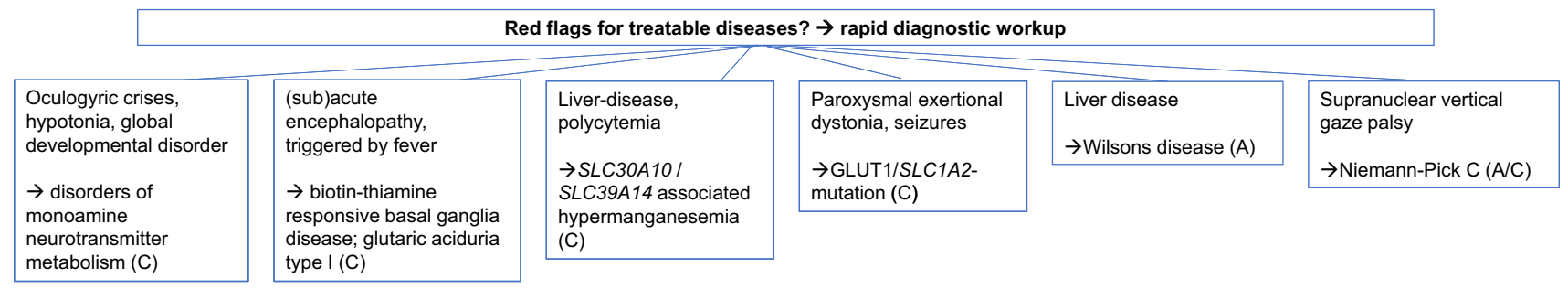

Fig. 2 Red flags for treatable diseases with complex dystonia; $\mathrm{A}=$ onset in adulthood; $\mathrm{C}=$ childhood-onset

Table 3 Overview of treatable forms of complex dystonia

\begin{tabular}{|c|c|}
\hline Disease & Causal treatment \\
\hline Disorders of monoamine neurotransmitter metabolism & $\begin{array}{l}\text { Supplementation with tetrahydrobiopterin, L-Dopa, } \\
\text { 5-hydroxytryptophan, or other dopaminergic medi- } \\
\text { cations }\end{array}$ \\
\hline GLUT1-deficiency & $\begin{array}{l}\text { Ketogenic diet } \\
\text { Triheptanoin }\end{array}$ \\
\hline Dystonia/parkinsonism with manganese accumulation (DYT/PARK-SLC30A10) & $\begin{array}{l}\text { EDTA-chelation therapy } \\
\text { Iron-therapy }\end{array}$ \\
\hline Glutaryl-CoA-dehydrogenase-deficiency (GCDH) & $\begin{array}{l}\text { Dietary lysin-restriction } \\
\text { L-Carnitine supplement } \\
\text { Prevention and management of known triggers }\end{array}$ \\
\hline Cystathionine beta-synthase deficiency (CBS) & $\begin{array}{l}\text { Vitamin B1/B6/B12 supplement } \\
\text { Dietary restriction of methionine/betaine }\end{array}$ \\
\hline Phenylketonuria & Dietary restriction of phenylalanine \\
\hline Biotinidase deficiency & Oral biotin supplements \\
\hline Galactosemia & Specific diet free of galactose and lactose \\
\hline Wilson's disease & Copper-chelating agents \\
\hline Leber's hereditary optic neuropathy "plus" & Idebenone \\
\hline Niemann-Pick type C & Miglustat \\
\hline
\end{tabular}

GLUT1 glucose transporter 1 
Given the rarity of many diseases associated with complex dystonias, evidence for the efficacy of a given medication is often very limited, so that rational treatment strategies for these diseases often have to be based on small clinical trials, expert opinion, or consensus statements (Jinnah et al. 2018).

In many patients with complex dystonia, symptomatic therapy is still the only option. Even if causative treatment is available, many patients still need additional support. Longterm personalized treatment should be planned and implemented in specialized multi-disciplinary centers, including physiotherapists, speech therapists, psychologists, and health care professionals in addition to neurologists and pediatric neurologists to support affected patients and their families, caregivers, and local physicians. Whenever possible patients should be included in disease registries and ongoing clinical trials necessitating close cooperation of specialized centers in national and international networks such as the ERN (see above) (Smith et al. 2020). Special transition services for young adults from neuro-pediatric to adult neurologic specialty centers should be offered or developed.

\section{Oral medication}

Oral medication is recommended for segmental and generalized dystonia. Particularly, trihexyphenidyl and baclofen can have a positive effect (Woo et al. 2020). The response to oral medication is variable.

\section{Trihexyphenidyl}

Trihexyphenidyl is an anticholinergic drug, which caused a significant benefit at a mean follow-up of 2.4 years in an early study (Burke et al. 1986b). The dose can slowly be increased, while side effects should be monitored, particularly sedation, dry mouth, blurred vision, and cognitive impairment (Taylor et al. 1991).

\section{Baclofen}

Baclofen is a pre-synaptic gamma-aminobutyric acid agonist. It can be used in combination with trihexyphenidyl for additional benefit. It has to be kept in mind that the main side effect is a general decrease in muscle tone, which can cause or increase pre-existing paresis and hypotonia. Additionally, sedation and dizziness can occur as side effects. If the medication is stopped, it must be tapered slowly to avoid withdrawal seizures (Thenganatt and Jankovic 2014).

\section{Other oral medications}

Tetrabenazine can improve dystonia, but is most frequently used for tardive dyskinesia.
L-Dopa is the mainstay of treatment in L-Dopa-responsive dystonias, but can also be tried in other forms of childhoodonset dystonia (Kitahara et al. 2009). Other agents shown to be effective in small case series or small trials include clonazepam, anticonvulsants, or muscle relaxants and can be tried to treat refractory dystonias (Thenganatt and Jankovic 2014).

\section{Botulinum neurotoxin}

Botulinum neurotoxin causing local muscle weakness due to peripheral chemical denervation is recommended as a firstline treatment for isolated focal and segmental dystonias (Albanese et al. 2011). Still, it can also be very effective in other forms of dystonia. Most patients have a long-term response after repeated treatment cycles (Ramirez-Castaneda and Jankovic 2014).

\section{Intrathecal baclofen}

Intrathecal baclofen often leads to significant improvement in children with severe spasticity and improves dystonia (Stewart et al. 2020). It is an established option in patients with treatment-refractory lower limb dystonia and spastic paraparesis. The main problems of this treatment are weakness, pump failure, or surgical complications. Treatment with intrathecal baclofen requires a specialized team to manage possible complications (Brennan and Whittle 2008).

\section{Deep brain stimulation (DBS)}

DBS of the internal globus pallidus is commonly used as a surgical treatment for various forms of generalized, segment, or focal dystonia (Tsuboi et al. 2020). Given the rarity of most complex dystonias, evidence for its usefulness in these patients is limited. DBS should be considered in therapy refractory cases, but should only be carried out in experienced centers after a careful risk-benefit assessment. Additionally, cases should be included in prospective clinical registries (Artusi et al. 2020).

\section{Conclusions}

In this review, we have highlighted the crucial role of interdisciplinary and cross-professional cooperation in the care of patients with complex dystonias with a special focus on the identification of treatable diseases. Prominent examples are disorders of monoamine neurotransmitter metabolism, Glut1-deficiency syndrome, Niemann-Pick Type C, and Wilson's disease. Future perspectives include an increasing role for the translation of insights from basic science 
regarding defined, often novel diseases, to clinical care, advances in early diagnosis by means of widely available online tools, and progress in digital case conferences. The development of specialized centers, mutually beneficial and dynamic networks for rare diseases, clinical registries, and structured training for rare diseases are pre-requisites for rational and personalized management of patients with complex dystonias.

Acknowledgements This work was supported by the DFG (SFB 936, project C5) and the Else Kröner-Fresenius Foundation (2018_A55). R.H., A.W., T.B., and A.M. are members of the European Reference Network for Rare Neurological Diseases_Project ID No 739510.

Author contributions Conceptualization: AM and RH. Literature search and drafting: RH. Critical revision: AM, TB, and AW.

Funding Open Access funding enabled and organized by Projekt DEAL. This work was supported by the DFG (SFB 936, project C5) and the Else Kröner-Fresenius Foundation (2018_A55). R.H., A.W., T.B., and A.M. are members of the European Reference Network for Rare Neurological Diseases-Project ID No 739510. R.H. is supported by the section of medicine of the University of Lübeck (CS08-2020).

\section{Compliance with ethical standards}

Conflict of interest The authors declare that they have no conflict of interest.

Open Access This article is licensed under a Creative Commons Attribution 4.0 International License, which permits use, sharing, adaptation, distribution and reproduction in any medium or format, as long as you give appropriate credit to the original author(s) and the source, provide a link to the Creative Commons licence, and indicate if changes were made. The images or other third party material in this article are included in the article's Creative Commons licence, unless indicated otherwise in a credit line to the material. If material is not included in the article's Creative Commons licence and your intended use is not permitted by statutory regulation or exceeds the permitted use, you will need to obtain permission directly from the copyright holder. To view a copy of this licence, visit http://creativecommons.org/licenses/by/4.0/.

\section{References}

Akcakaya NH, Haryanyan G, Mercan S, Sozer N, Ali A, Tombul T, Ozbek U, Ugur Iseri SA, Yapici Z (2019) Clinical and genetic spectrum of an orphan disease MPAN: a series with new variants and a novel phenotype. Neurol Neurochir Pol 53(6):476-483. https://doi.org/10.5603/PJNNS.a2019.0062

Ala A, Borjigin J, Rochwarger A, Schilsky M (2005) Wilson disease in septuagenarian siblings: raising the bar for diagnosis. Hepatology 41(3):668-670. https://doi.org/10.1002/hep.20601

Albanese A, Asmus F, Bhatia KP, Elia AE, Elibol B, Filippini G, Gasser T, Krauss JK, Nardocci N, Newton A, Valls-Sole J (2011) EFNS guidelines on diagnosis and treatment of primary dystonias. Eur J Neurol 18(1):5-18. https://doi.org/10.111 1/j.1468-1331.2010.03042.x

Alfadhel M, Almuntashri M, Jadah RH, Bashiri FA, Al Rifai MT, Al Shalaan H, Al Balwi M, Al Rumayan A, Eyaid W, Al-Twaijri
W (2013) Biotin-responsive basal ganglia disease should be renamed biotin-thiamine-responsive basal ganglia disease: a retrospective review of the clinical, radiological and molecular findings of 18 new cases. Orphanet J Rare Dis 8:83. https://doi. org/10.1186/1750-1172-8-83

Alter AS, Engelstad K, Hinton VJ, Montes J, Pearson TS, Akman CI, De Vivo DC (2015) Long-term clinical course of Glut1 deficiency syndrome. J Child Neurol 30(2):160-169. https://doi. org/10.1177/0883073814531822

Amalou S, Gras D, Ilea A, Greneche MO, Francois L, Bellavoine V, Delanoe C, Auvin S (2016) Use of modified Atkins diet in glucose transporter type 1 deficiency syndrome. Dev Med Child Neurol 58(11):1193-1199. https://doi.org/10.1111/dmcn.13167

Armstrong RA (2011) Visual signs and symptoms of progressive supranuclear palsy. Clin Exp Optom 94(2):150-160. https://doi.org/1 0.1111/j.1444-0938.2010.00504.x

Armstrong MJ, Litvan I, Lang AE, Bak TH, Bhatia KP, Borroni B, Boxer AL, Dickson DW, Grossman M, Hallett M, Josephs KA, Kertesz A, Lee SE, Miller BL, Reich SG, Riley DE, Tolosa E, Troster AI, Vidailhet M, Weiner WJ (2013) Criteria for the diagnosis of corticobasal degeneration. Neurology 80(5):496-503. https://doi.org/10.1212/WNL.0b013e31827f0fd1

Artusi CA, Dwivedi A, Romagnolo A, Bortolani S, Marsili L, Imbalzano G, Sturchio A, Keeling EG, Zibetti M, Contarino MF, Fasano A, Tagliati M, Okun MS, Espay AJ, Lopiano L, Merola A (2020) Differential response to pallidal deep brain stimulation among monogenic dystonias: systematic review and metaanalysis. J Neurol Neurosurg Psychiatry 91(4):426-433. https:// doi.org/10.1136/jnnp-2019-322169

Bajwa H, Azhar W (2020) Niemann-pick disease. StatPearls, Treasure Island

Barclay CL, Lang AE (1997) Dystonia in progressive supranuclear palsy. J Neurol Neurosurg Psychiatry 62(4):352-356. https://doi. org/10.1136/jnnp.62.4.352

Baumeister FA, Auer DP, Hortnagel K, Freisinger P, Meitinger T (2005) The eye-of-the-tiger sign is not a reliable disease marker for Hallervorden-Spatz syndrome. Neuropediatrics 36(3):221222. https://doi.org/10.1055/s-2005-865714

Baumer T, Sajin V, Munchau A (2017) Childhood-onset movement disorders: a clinical series of 606 cases. Mov Disord Clin Pract 4(3):437-440. https://doi.org/10.1002/mdc3.12399

Benini R, Dagenais L, Shevell MI, de la Paralysie R, Quebec CC (2013) Normal imaging in patients with cerebral palsy: what does it tell us? J Pediatr 162(2):369-374. https://doi.org/10.1016/j.jpeds .2012 .07 .044

Brennan PM, Whittle IR (2008) Intrathecal baclofen therapy for neurological disorders: a sound knowledge base but many challenges remain. Br J Neurosurg 22(4):508-519. https://doi. org/10.1080/02688690802233364

Brissot P, Ropert M, Le Lan C, Loreal O (2012) Non-transferrin bound iron: a key role in iron overload and iron toxicity. Biochim Biophys Acta 3:403-410. https://doi.org/10.1016/j.bbage n.2011.07.014

Burke RE, Brin MF, Fahn S, Bressman SB, Moskowitz C (1986a) Analysis of the clinical course of non-Jewish, autosomal dominant torsion dystonia. Mov Disord 1(3):163-178. https://doi. org/10.1002/mds.870010302

Burke RE, Fahn S, Marsden CD (1986b) Torsion dystonia: a doubleblind, prospective trial of high-dosage trihexyphenidyl. Neurology 36(2):160-164. https://doi.org/10.1212/wnl.36.2.160

Burke JF, Dayalu P, Nan B, Askari F, Brewer GJ, Lorincz MT (2011) Prognostic significance of neurologic examination findings in Wilson disease. Parkinsonism Relat Disord 17(7):551-556. https ://doi.org/10.1016/j.parkreldis.2011.05.002

Chang FC, Westenberger A, Dale RC, Smith M, Pall HS, Perez-Duenas B, Grattan-Smith P, Ouvrier RA, Mahant N, Hanna BC, Hunter 
M, Lawson JA, Max C, Sachdev R, Meyer E, Crimmins D, Pryor D, Morris JG, Munchau A, Grozeva D, Carss KJ, Raymond L, Kurian MA, Klein C, Fung VS (2016) Phenotypic insights into ADCY5-associated disease. Mov Disord 31(7):1033-1040. https ://doi.org/10.1002/mds.26598

Chen YZ, Matsushita MM, Robertson P, Rieder M, Girirajan S, Antonacci F, Lipe H, Eichler EE, Nickerson DA, Bird TD, Raskind WH (2012) Autosomal dominant familial dyskinesia and facial myokymia: single exome sequencing identifies a mutation in adenylyl cyclase 5. Arch Neurol 69(5):630-635. https://doi. org/10.1001/archneurol.2012.54

Christine C, Dolk H, Platt MJ, Colver A, Prasauskiene A, KragelohMann I, Group SC (2007) Recommendations from the SCPE collaborative group for defining and classifying cerebral palsy. Dev Med Child Neurol Suppl 109:35-38. https://doi. org/10.1111/j.1469-8749.2007.tb12626.x

Dennery PA, Seidman DS, Stevenson DK (2001) Neonatal hyperbilirubinemia. N Engl J Med 344(8):581-590. https://doi.org/10.1056/ NEJM200102223440807

Donzuso G, Mostile G, Nicoletti A, Zappia M (2019) Basal ganglia calcifications (Fahr's syndrome): related conditions and clinical features. Neurol Sci 40(11):2251-2263. https://doi.org/10.1007/ s10072-019-03998-x

Ebrahimi-Fakhari D, Van Karnebeek C, Munchau A (2019) Movement disorders in treatable inborn errors of metabolism. Mov Disord 34(5):598-613. https://doi.org/10.1002/mds.27568

Evers C, Seitz A, Assmann B, Opladen T, Karch S, Hinderhofer K, Granzow M, Paramasivam N, Eils R, Diessl N, Bartram CR, Moog U (2017) Diagnosis of CoPAN by whole exome sequencing: Waking up a sleeping tiger's eye. Am J Med Genet A 173(7):1878-1886. https://doi.org/10.1002/ajmg.a.38252

Giri S, Naiya T, Roy S, Das G, Wali GM, Das SK, Ray K, Ray J (2019) A compound heterozygote for GCH1 mutation represents a case of atypical dopa-responsive dystonia. J Mol Neurosci 68(2):214 220. https://doi.org/10.1007/s12031-019-01301-3

Gkoltsiou K, Tzoufi M, Counsell S, Rutherford M, Cowan F (2008) Serial brain MRI and ultrasound findings: relation to gestational age, bilirubin level, neonatal neurologic status and neurodevelopmental outcome in infants at risk of kernicterus. Early Hum Dev 84(12):829-838. https://doi.org/10.1016/j. earlhumdev.2008.09.008

Greene P, Kang UJ, Fahn S (1995) Spread of symptoms in idiopathic torsion dystonia. Mov Disord 10(2):143-152. https:// doi.org/10.1002/mds.870100204

Gregory A, Hayflick S (1993) Neurodegeneration with brain iron accumulation disorders overview. In: Adam MP, Ardinger HH, Pagon RA (eds) GeneReviews((R)). Statpearls, Seattle

Gregory A, Kurian MA, Maher ER, Hogarth P, Hayflick SJ (1993) In: Adam MP, Ardinger HH, Pagon RA et al (eds) PLA2G6Associated Neurodegeneration. GeneReviews((R)), Seattle (WA)

Haack TB, Hogarth P, Kruer MC, Gregory A, Wieland T, Schwarzmayr T, Graf E, Sanford L, Meyer E, Kara E, Cuno SM, Harik SI, Dandu VH, Nardocci N, Zorzi G, Dunaway T, Tarnopolsky M, Skinner S, Frucht S, Hanspal E, Schrander-Stumpel C, Heron D, Mignot C, Garavaglia B, Bhatia K, Hardy J, Strom TM, Boddaert N, Houlden HH, Kurian MA, Meitinger T, Prokisch H, Hayflick SJ (2012) Exome sequencing reveals de novo WDR45 mutations causing a phenotypically distinct, X-linked dominant form of NBIA. Am J Hum Genet 91(6):1144-1149. https://doi.org/10.1016/j.ajhg.2012.10.019

Hayflick SJ, Westaway SK, Levinson B, Zhou B, Johnson MA, Ching KH, Gitschier J (2003) Genetic, clinical, and radiographic delineation of Hallervorden-Spatz syndrome. N Engl J Med 348(1):33-40. https://doi.org/10.1056/NEJMoa020817
Hermann W (2014) Morphological and functional imaging in neurological and non-neurological Wilson's patients. Ann N Y Acad Sci 1315:24-29. https://doi.org/10.1111/nyas.12343

Hinkley LB, Webster RL, Byl NN, Nagarajan SS (2009) Neuroimaging characteristics of patients with focal hand dystonia. J Hand Ther 22(2):125-134. https://doi.org/10.1016/j.jht.2008.11.002

Jinnah HA, Albanese A, Bhatia KP, Cardoso F, Da Prat G, de Koning TJ, Espay AJ, Fung V, Garcia-Ruiz PJ, Gershanik O, Jankovic J, Kaji R, Kotschet K, Marras C, Miyasaki JM, Morgante F, Munchau A, Pal PK, Rodriguez Oroz MC, Rodriguez-Violante M, Schols L, Stamelou M, Tijssen M, Uribe Roca C, de la Cerda A, Gatto EM, International Parkinson's Disease Movement Disorders Society Task Force on Rare Movement D (2018) Treatable inherited rare movement disorders. Mov Disord 33(1):21-35. https://doi.org/10.1002/mds.27140

Kitahara M, Shimohata T, Tokunaga J, Nishizawa M (2009) Cervical dystonia associated with spinocerebellar ataxia type 2 successfully treated with levodopa: a case report. Mov Disord 24(14):2163-2164. https://doi.org/10.1002/mds.22756

Klein C, Munchau A (2013) Progressive dystonia. Handb Clin Neurol 113:1889-1897. https://doi.org/10.1016/B978-0-444-59565 $-2.00059-9$

Klein C, Lohmann K, Marras C, Munchau A (1993) Hereditary dystonia overview. In: Adam MP, Ardinger HH, Pagon RA (eds) GeneReviews((R)). Statpearls, Seattle

Klopstock T, Tricta F, Neumayr L, Karin I, Zorzi G, Fradette C, Kmiec T, Buchner B, Steele HE, Horvath R, Chinnery PF, Basu A, Kupper C, Neuhofer C, Kalman B, Dusek P, Yapici Z, Wilson I, Zhao F, Zibordi F, Nardocci N, Aguilar C, Hayflick SJ, Spino M, Blamire AM, Hogarth P, Vichinsky E (2019) Safety and efficacy of deferiprone for pantothenate kinase-associated neurodegeneration: a randomised, doubleblind, controlled trial and an open-label extension study. Lancet Neurol 18(7):631-642. https://doi.org/10.1016/S1474 $-4422(19) 30142-5$

Krack P, Marion MH (1994) "Apraxia of lid opening," a focal eyelid dystonia: clinical study of 32 patients. Mov Disord 9(6):610-615. https://doi.org/10.1002/mds.870090605

Kurian MA, Hayflick SJ (2013) Pantothenate kinase-associated neurodegeneration (PKAN) and PLA2G6-associated neurodegeneration (PLAN): review of two major neurodegeneration with brain iron accumulation (NBIA) phenotypes. Int Rev Neurobiol 110:49-71. https://doi.org/10.1016/B978-0-12-410502-7.00003 $-\mathrm{X}$

Kubota A, Hida A, Ichikawa Y, Momose Y, Goto J, Igeta Y, Hashida H, Yoshida K, Ikeda S, Kanazawa I, Tsuji S (2009) A novel ferritin light chain gene mutation in a Japanese family with neuroferritinopathy: description of clinical features and implications for genotype-phenotype correlations. Mov Disord 24:(3):441-445. https://doi.org/10.1002/mds.22435

Legido A, Zimmerman RA, Packer RJ, Bilaniuk LT, Siegel KR, D’Angio G (1988) Significance of basal ganglia calcification on computed tomography in children. Pediatr Neurosci 14(2):64-70. https://doi.org/10.1159/000120365

Lehericy S, Roze E, Goizet C, Mochel F (2020) MRI of neurodegeneration with brain iron accumulation. Curr Opin Neurol 33(4):462473. https://doi.org/10.1097/WCO.0000000000000844

Letort D, Gonzalez-Alegre P (2013) Huntington's disease in children. Handb Clin Neurol 113:1913-1917. https://doi.org/10.1016/ B978-0-444-59565-2.00061-7

Levi S, Cozzi A, Santambrogio P (2019) Iron pathophysiology in neurodegeneration with brain iron accumulation. Adv Exp Med Biol 1173:153-177. https://doi.org/10.1007/978-981-13-9589-5_9

Lin JP, Lumsden DE, Gimeno H, Kaminska M (2014) The impact and prognosis for dystonia in childhood including dystonic cerebral palsy: a clinical and demographic tertiary cohort study. 
J Neurol Neurosurg Psychiatry 85(11):1239-1244. https://doi. org/10.1136/jnnp-2013-307041

Lingen M, Albers L, Borchers M, Haass S, Gartner J, Schroder S, Goldbeck L, von Kries R, Brockmann K, Zirn B (2016) Obtaining a genetic diagnosis in a child with disability: impact on parental quality of life. Clin Genet 89(2):258-266. https://doi. org/10.1111/cge.12629

Maccarinelli F, Pagani A, Cozzi A, Codazzi F, Di Giacomo G, Capoccia S, Rapino S, Finazzi D, Politi LS, Cirulli F, Giorgio M, Cremona O, Grohovaz F, Levi S (2015) A novel neuroferritinopathy mouse model (FTL 498InsTC) shows progressive brain iron dysregulation, morphological signs of early neurodegeneration and motor coordination deficits. Neurobiol Dis 81:119-133. https:// doi.org/10.1016/j.nbd.2014.10.023

Machado A, Chien HF, Deguti MM, Cancado E, Azevedo RS, Scaff M, Barbosa ER (2006) Neurological manifestations in Wilson's disease: report of 119 cases. Mov Disord 21(12):2192-2196. https://doi.org/10.1002/mds.21170

MacLennan AH, Thompson SC, Gecz J (2015) Cerebral palsy: causes, pathways, and the role of genetic variants. Am J Obstet Gynecol 213(6):779-788. https://doi.org/10.1016/j.ajog.2015.05.034

Marchi G, Busti F, Lira Zidanes A, Castagna A, Girelli D (2019) Aceruloplasminemia: a severe neurodegenerative disorder deserving an early diagnosis. Front Neurosci 13:325. https://doi. org/10.3389/fnins.2019.00325

Mari F, Berti B, Romano A, Baldacci J, Rizzi R, Grazia Alessandri M, Tessa A, Procopio E, Rubegni A, Lourenco CM, Simonati A, Guerrini R, Santorelli FM (2018) Clinical and neuroimaging features of autosomal recessive spastic paraplegia 35 (SPG35): case reports, new mutations, and brief literature review. Neurogenetics 19(2):123-130. https://doi.org/10.1007/s10048-018-0538-8

Marsden CD, Harrison MJ (1974) Idiopathic torsion dystonia (dystonia musculorum deformans). A review of forty-two patients. Brain 97(4):793-810. https://doi.org/10.1093/brain/97.1.793

Merle U, Schaefer M, Ferenci P, Stremmel W (2007) Clinical presentation, diagnosis and long-term outcome of Wilson's disease: a cohort study. Gut 56(1):115-120. https://doi.org/10.1136/ gut.2005.087262

Mulligan C, Bronstein JM (2020) Wilson disease: an overview and approach to management. Neurol Clin 38(2):417-432. https:// doi.org/10.1016/j.ncl.2020.01.005

Munchau A, Mathen D, Cox T, Quinn NP, Marsden CD, Bhatia KP (2000) Unilateral lesions of the globus pallidus: report of four patients presenting with focal or segmental dystonia. J Neurol Neurosurg Psychiatry 69(4):494-498. https://doi.org/10.1136/ jnnp.69.4.494

Munchau A, Schols L, Klein C, Graessner H (2019) Model for personalized diagnostics and treatment in neurology-German Academy for Rare Neurological Diseases. Nervenarzt 90(8):796-803. https ://doi.org/10.1007/s00115-019-0750-2

Olusanya BO, Ogunlesi TA, Slusher TM (2014) Why is kernicterus still a major cause of death and disability in low-income and middle-income countries? Arch Dis Child 99(12):1117-1121. https://doi.org/10.1136/archdischild-2013-305506

Olusanya BO, Osibanjo FB, Slusher TM (2015) Risk factors for severe neonatal hyperbilirubinemia in low and middle-income countries: a systematic review and meta-analysis. PLoS ONE 10(2):e0117229. https://doi.org/10.1371/journal.pone.0117229

Opladen T, Lopez-Laso E, Cortes-Saladelafont E, Pearson TS, Sivri HS, Yildiz Y, Assmann B, Kurian MA, Leuzzi V, Heales S, Pope S, Porta F, Garcia-Cazorla A, Honzik T, Pons R, Regal L, Goez H, Artuch R, Hoffmann GF, Horvath G, Thony B, Scholl-Burgi S, Burlina A, Verbeek MM, Mastrangelo M, Friedman J, Wassenberg T, Jeltsch K, Kulhanek J, Hubschmann OH, International Working Group on Neurotransmitter related D (2020) Consensus guideline for the diagnosis and treatment of tetrahydrobiopterin
(BH4) deficiencies. Orphanet J Rare Dis 15(1):126. https://doi. org/10.1186/s13023-020-01379-8

Pakula AT, Van Naarden BK, Yeargin-Allsopp M (2009) Cerebral palsy: classification and epidemiology. Phys Med Rehabil Clin N Am 20(3):425-452. https://doi.org/10.1016/j.pmr.2009.06.001

Patterson MC, Mengel E, Vanier MT, Moneuse P, Rosenberg D, Pineda M (2020) Treatment outcomes following continuous miglustat therapy in patients with Niemann-Pick disease Type C: a final report of the NPC Registry. Orphanet J Rare Dis 15(1):104. https ://doi.org/10.1186/s13023-020-01363-2

Pearson TS, Pons R, Ghaoui R, Sue CM (2019) Genetic mimics of cerebral palsy. Mov Disord 34(5):625-636. https://doi.org/10.1002/ mds. 27655

Pons R, Collins A, Rotstein M, Engelstad K, De Vivo DC (2010) The spectrum of movement disorders in Glut-1 deficiency. Mov Disord 25(3):275-281. https://doi.org/10.1002/mds.22808

Pourcher E, Cohen H, Cohen D, Baruch P, Bouchard RH (1993) Organic brain dysfunction and cognitive deficits in young schizophrenic patients with tardive dyskinesia. Brain Cogn 23(1):8187. https://doi.org/10.1006/brcg.1993.1046

Quarrell OW, Nance MA, Nopoulos P, Paulsen JS, Smith JA, Squitieri F (2013) Managing juvenile Huntington's disease. Neurodegener Dis Manag. https://doi.org/10.2217/nmt.13.18

Ramirez-Castaneda J, Jankovic J (2014) Long-term efficacy, safety, and side effect profile of botulinum toxin in dystonia: a 20-year follow-up. Toxicon 90:344-348. https://doi.org/10.1016/j.toxic on.2014.07.009

Rattay TW, Lindig T, Baets J, Smets K, Deconinck T, Sohn AS, Hortnagel K, Eckstein KN, Wiethoff S, Reichbauer J, DoblerNeumann M, Krageloh-Mann I, Auer-Grumbach M, Plecko B, Munchau A, Wilken B, Janauschek M, Giese AK, De Bleecker JL, Ortibus E, Debyser M, Lopez de Munain A, Pujol A, Bassi MT, D'Angelo MG, De Jonghe P, Zuchner S, Bauer P, Schols L, Schule R (2019) FAHN/SPG35: a narrow phenotypic spectrum across disease classifications. Brain 142(6):1561-1572. https:// doi.org/10.1093/brain/awz102

Rohani M, Razmeh S, Shahidi GA, Alizadeh E, Orooji M (2017) A pilot trial of deferiprone in pantothenate kinase-associated neurodegeneration patients. Neurol Int 9(4):7279. https://doi. org/10.4081/ni.2017.7279

Rose J, Vassar R (2015) Movement disorders due to bilirubin toxicity. Semin Fetal Neonatal Med 20(1):20-25. https://doi. org/10.1016/j.siny.2014.11.002

Sandu C, Burloiu CM, Barca DG, Magureanu SA, Craiu DC (2019) Ketogenic diet in patients with GLUT1 deficiency syndrome. Maedica (Buchar) 14(2):93-97. https://doi.org/10.26574/maedi ca.2019.14.2.93

Santambrogio P, Dusi S, Guaraldo M, Rotundo LI, Broccoli V, Garavaglia B, Tiranti V, Levi S (2015) Mitochondrial iron and energetic dysfunction distinguish fibroblasts and induced neurons from pantothenate kinase-associated neurodegeneration patients. Neurobiol Dis 81:144-153. https://doi.org/10.1016/j. nbd.2015.02.030

Santambrogio P, Ripamonti M, Paolizzi C, Panteghini C, Carecchio M, Chiapparini L, Raimondi M, Rubio A, Di Meo I, Cozzi A, Taverna S, De Palma G, Tiranti V, Levi S (2020) Harmful ironcalcium relationship in pantothenate kinase associated neurodegeneration. Int J Mol Sci. https://doi.org/10.3390/ijms21103664

Schneider SA, Bhatia KP (2010) Secondary dystonia-clinical clues and syndromic associations. Eur J Neurol 17(Suppl 1):52-57. https ://doi.org/10.1111/j.1468-1331.2010.03051.x

Schubert Baldo M, Vilarinho L (2020) Correction to: Molecular basis of Leigh syndrome: a current look. Orphanet J Rare Dis 15(1):77. https://doi.org/10.1186/s13023-020-1351-7 
Sedel F (2010) Clinical diagnosis of the adult form of Niemann-Pick type C disease. Arch Pediatr 17(Suppl 2):S50-53. https://doi. org/10.1016/S0929-693X(10)70012-9

Seibler P, Burbulla LF, Dulovic M, Zittel S, Heine J, Schmidt T, Rudolph F, Westenberger A, Rakovic A, Munchau A, Krainc $\mathrm{D}$, Klein C (2018) Iron overload is accompanied by mitochondrial and lysosomal dysfunction in WDR45 mutant cells. Brain 141(10):3052-3064. https://doi.org/10.1093/brain/awy230

Shapiro SM (2005) Definition of the clinical spectrum of kernicterus and bilirubin-induced neurologic dysfunction (BIND). J Perinatol 25(1):54-59. https://doi.org/10.1038/sj.jp.7211157

Shapiro SM (2010) Chronic bilirubin encephalopathy: diagnosis and outcome. Semin Fetal Neonatal Med 15(3):157-163. https://doi. org/10.1016/j.siny.2009.12.004

Shapiro SM, Riordan SM (2020) Review of bilirubin neurotoxicity II: preventing and treating acute bilirubin encephalopathy and kernicterus spectrum disorders. Pediatr Res 87(2):332-337. https ://doi.org/10.1038/s41390-019-0603-5

Shetty AS, Bhatia KP, Lang AE (2019) Dystonia and Parkinson's disease: what is the relationship? Neurobiol Dis 132:104462. https ://doi.org/10.1016/j.nbd.2019.05.001

Smith M, Alexander E, Marcinkute R, Dan D, Rawson M, Banka S, Gavin J, Mina H, Hennessy C, Riccardi F, Radio FC, Havlovicova M, Cassina M, Emandi AC, Fradin M, Gompertz L, Nordgren A, Traberg R, Rossi M, Trimouille A, Sowmyalakshmi R, Dallapiccola B, Renieri A, Faivre L, Kerr B, Verloes A, Clayton-Smith J, Douzgou S, Ern I (2020) Telemedicine strategy of the European Reference Network ITHACA for the diagnosis and management of patients with rare developmental disorders. Orphanet J Rare Dis 15(1):103. https://doi.org/10.1186/s1302 3-020-1349-1

Stelten BML, van Ommen W, Keizer K (2019) Neurodegeneration with brain iron accumulation: a novel mutation in the ceruloplasmin gene. JAMA Neurol 76(2):229-230. https://doi.org/10.1001/ jamaneurol.2018.3230

Stewart K, Copeland L, Lewis J (2020) The impact of intrathecal baclofen therapy on health-related quality of life for children with marked hypertonia. Dev Neurorehabil. https://doi. org/10.1080/17518423.2020.1753841

Svetel M, Tomic A, Dragasevic N, Petrovic I, Kresojevic N, Jech R, Urgosik D, Banjac I, Vitkovic J, Novakovic I, Kostic VS (2019) Clinical course of patients with pantothenate kinase-associated neurodegeneration (PKAN) before and after DBS surgery. J Neurol 266(12):2962-2969. https://doi.org/10.1007/s00415-01909499-3

Tabarki B, Al-Shafi S, Al-Shahwan S, Azmat Z, Al-Hashem A, AlAdwani N, Biary N, Al-Zawahmah M, Khan S, Zuccoli G (2013) Biotin-responsive basal ganglia disease revisited: clinical, radiologic, and genetic findings. Neurology 80(3):261-267. https:// doi.org/10.1212/WNL.0b013e31827deb4c

Tabarki B, Alfadhel M, AlShahwan S, Hundallah K, AlShafi S, AlHashem A (2015) Treatment of biotin-responsive basal ganglia disease: Open comparative study between the combination of biotin plus thiamine versus thiamine alone. Eur J Paediatr Neurol 19(5):547-552. https://doi.org/10.1016/j.ejpn.2015.05.008

Taylor AE, Lang AE, Saint-Cyr JA, Riley DE, Ranawaya R (1991) Cognitive processes in idiopathic dystonia treated with highdose anticholinergic therapy: implications for treatment strategies. Clin Neuropharmacol 14(1):62-77. https://doi. org/10.1097/00002826-199102000-00005

Thenganatt MA, Jankovic J (2014) Treatment of dystonia. Neurotherapeutics 11(1):139-152. https://doi.org/10.1007/s1331 1-013-0231-4

Thenganatt MA, Jankovic J (2015) Psychogenic movement disorders. Neurol Clin 33(1):205-224. https://doi.org/10.1016/j. ncl.2014.09.013
Thongchuam Y, Panyakaew P, Bhidayasiri R (2020) Orofacial dystonia and asssociated bulbar symptoms in multiple system atrophy: A blinded video analysis. J Neurol Sci. https://doi.org/10.1016/j. jns.2020.116992

Timmermann L, Pauls KA, Wieland K, Jech R, Kurlemann G, Sharma N, Gill SS, Haenggeli CA, Hayflick SJ, Hogarth P, Leenders KL, Limousin P, Malanga CJ, Moro E, Ostrem JL, Revilla FJ, Santens P, Schnitzler A, Tisch S, Valldeoriola F, Vesper J, Volkmann J, Woitalla D, Peker S (2010) Dystonia in neurodegeneration with brain iron accumulation: outcome of bilateral pallidal stimulation. Brain 133(Pt 3):701-712. https://doi.org/10.1093/brain/ awq022

Tonduti D, Panteghini C, Pichiecchio A, Decio A, Carecchio M, Reale C, Moroni I, Nardocci N, Campistol J, Garcia-Cazorla A, Perez Duenas B, Cerebral Calcification International Study G, Chiapparini L, Garavaglia B, Orcesi S (2018) Encephalopathies with intracranial calcification in children: clinical and genetic characterization. Orphanet J Rare Dis 13(1):135. https://doi. org/10.1186/s13023-018-0854-y

Tsuboi T, Cauraugh JH, Wong JK, Okun MS, Ramirez-Zamora A (2020) Quality of life outcomes after globus pallidus internus deep brain stimulation in idiopathic or inherited isolated dystonia: a meta-analysis. J Neurol Neurosurg Psychiatry. https://doi. org/10.1136/jnnp-2019-322575

Tunc S, Bruggemann N, Baaske MK, Hartmann C, Grutz K, Westenberger A, Klein C, Munchau A, Baumer T (2017) Facial twitches in ADCY5-associated disease - Myokymia or myoclonus? An electromyography study. Parkinsonism Relat Disord 40:73-75. https://doi.org/10.1016/j.parkreldis.2017.04.013

van Egmond ME, Lugtenberg CHA, Brouwer OF, Contarino MF, Fung VSC, Heiner-Fokkema MR, van Hilten JJ, van der Hout AH, Peall KJ, Sinke RJ, Roze E, Verschuuren-Bemelmans CC, Willemsen MA, Wolf NI, Tijssen MA, de Koning TJ (2017) A post hoc study on gene panel analysis for the diagnosis of dystonia. Mov Disord 32(4):569-575. https://doi.org/10.1002/mds.26937

van Egmond ME, Eggink H, Kuiper A, Sival DA, Verschuuren-Bemelmans CC, Tijssen MAJ, de Koning TJ (2018) Crossing barriers: a multidisciplinary approach to children and adults with youngonset movement disorders. J Clin Mov Disord 5:3. https://doi. org/10.1186/s40734-018-0070-x

Weiss KH, Thurik F, Gotthardt DN, Schafer M, Teufel U, Wiegand F, Merle U, Ferenci-Foerster D, Maieron A, Stauber R, Zoller H, Schmidt HH, Reuner U, Hefter H, Trocello JM, Houwen RH, Ferenci P, Stremmel W, Consortium E (2013) Efficacy and safety of oral chelators in treatment of patients with Wilson disease. Clin Gastroenterol Hepatol 11(8):1028-1035. https://doi. org/10.1016/j.cgh.2013.03.012

Weiss KH, Czlonkowska A, Hedera P, Ferenci P (2018) WTX101 - an investigational drug for the treatment of Wilson disease. Expert Opin Investig Drugs 27(6):561-567. https://doi. org/10.1080/13543784.2018.1482274

Went LN, Vegter-van der Vlis M, Bruyn GW (1984) Parental transmission in Huntington's disease. Lancet 1(8386):1100-1102. https ://doi.org/10.1016/s0140-6736(84)92510-8

Wijburg FA, Sedel F, Pineda M, Hendriksz CJ, Fahey M, Walterfang M, Patterson MC, Wraith JE, Kolb SA (2012) Development of a suspicion index to aid diagnosis of Niemann-Pick disease type C. Neurology 78(20):1560-1567. https://doi.org/10.1212/ WNL.0b013e3182563b82

Woo KA, Kim HJ, Yoo D, Choi JH, Shin J, Park S, Kim R, Jeon B (2020) Patient-reported responses to medical treatment in primary dystonia. J Clin Neurosci 75:242-244. https://doi. org/10.1016/j.jocn.2020.03.025

Xu Y, Zhang Q, Tan L, Xie X, Zhao Y (2019) The characteristics and biological significance of NPC2: mutation and disease. Mutat Res 782:108284. https://doi.org/10.1016/j.mrrev.2019.108284 
Yamada M, Asano T, Okamoto K, Hayashi Y, Kanematsu M, Hoshi H, Akaiwa Y, Shimohata T, Nishizawa M, Inuzuka T, Hozumi I (2013) High frequency of calcification in basal ganglia on brain computed tomography images in Japanese older adults. Geriatr Gerontol Int 13(3):706-710. https://doi.org/10.1111/ggi.12004

Zimbrean PC, Schilsky ML (2014) Psychiatric aspects of Wilson disease: a review. Gen Hosp Psychiatry 36(1):53-62. https://doi. org/10.1016/j.genhosppsych.2013.08.007

Zorzi G, Zibordi F, Chiapparini L, Bertini E, Russo L, Piga A, Longo F, Garavaglia B, Aquino D, Savoiardo M, Solari A, Nardocci N (2011) Iron-related MRI images in patients with pantothenate kinase-associated neurodegeneration (PKAN) treated with deferiprone: results of a phase II pilot trial. Mov Disord 26(9):17561759. https://doi.org/10.1002/mds.23751
Zouvelou V, Yubero D, Apostolakopoulou L, Kokkinou E, Bilanakis M, Dalivigka Z, Nikas I, Kollia E, Perez-Duenas B, Macaya A, Marce-Grau A, Voutetakis A, Anagnostopoulou K, Kekou K, Sofocleus C, Veltra D, Kokkinis X, Fryssira H, Torres RJ, Amstrong J, Santorelli FM, Artuch R, Pons R (2019) The genetic etiology in cerebral palsy mimics: the results from a Greek tertiary care center. Eur J Paediatr Neurol 23(3):427-437. https:// doi.org/10.1016/j.ejpn.2019.02.001

Publisher's Note Springer Nature remains neutral with regard to jurisdictional claims in published maps and institutional affiliations. 